\title{
Specification of the Climate Character in the Study Area of Projected Hydric Reclamation
}

\author{
Dagmar DLOUHÁ ${ }^{1)}$, Viktor DUBOVSK $\hat{Y}^{2)}$
}

\footnotetext{
1) Mgr. PhD.; VŠB-Technical university of Ostrava, Faculty of Civil Engineering, Ludvíka Podéště 1875/17, 70833 Ostrava-Poruba, Czech Republic; email: dagmar.dlouha@vsb.cz

2) RNDr. PhD.; VŠB-Technical university of Ostrava, Faculty of Civil Engineering, Ludvíka Podéště 1875/17, 70833 Ostrava-Poruba, Czech Republic; email: viktor.dubovsky@vsb.cz
}

http://doi.org/10.29227/IM-2021-01-10

Submission date: 29-01-2021 | Review date: 06-05-2021

\begin{abstract}
Hydrical reclamation of the residual pit of Most-Ležáky is part of the comprehensive revitalisation of the land affected in the past by mining activity with an area of $1264 \mathrm{ha}$. Thus, in terms of remediation and reclamation, the most appropriate way to reclaim the residual pit, as one of the final stages of the long-term reclamation activities that have been going on in the area for more than half a century, occurs under the given conditions. The Lake Most, our study area, was planned and created as a hydric recultivation of the former surface Most-Ležáky mine located near the town of Most, in the foothills of the Ore Mountains, approximately 80 kilometers northwest of the capital of the Czech Republic - Prague. The Lake Most represents extensive hydric reclamation, which is unique in the sense that it does not have a natural inflow and runoff, therefore an artificial feeder from the Ohre River had to be built. The main goal of the ongoing research is to construct a mathematical model predicting the water balance of Lake Most. Therefore, it is important to separate amount of water that is lost by the evaporation and amount of water that is lost into the subsoil. If we do not wish to use only temperature equations but more complex methods and equations to calculate evaporation instead, we need to have relative humidity, atmospheric pressure, wind speed, and daylight length values. In addition to the climatic data needed to calculate the evaporation, the amount of precipitation is needed to construct the balance equation of the area. An important objective in planning all hydric reclamations is to ensure their long-term sustainability, which is based on a detailed description of the study area's climate and local hydrological conditions. In our article we focus on assessing the evolution of climate in the area of this hydric reclamation. We have processed a long-term series of measurements in monthly averages from the Kopisty meteostation data provided by the Institute of Atmospheric Physics of the CAS.
\end{abstract}

Keywords: climate, evaporation, hydric reclamation, Lake Most

\section{Introduction}

The issue of free water surface evaporation is highly topical in relation to the sinking of pits after surface mining, given the nature of the weather in recent years. The impact of water surface evaporation on the overall hydrological balance of a river basin can be significant, especially in years with low annual precipitation. Currently, the increasing air temperatures appear to be the biggest problem, resulting in increased territorial as well as water surface evaporation. These water losses from the hydrological system are not sufficiently compensated by annual precipitation, which is unevenly distributed across the territory of the Czech Republic, and thus there are areas in the Czech Republic where the total evaporation exceeds precipitation and drought effects can be observed, see, e.g. (Beran \& Hanel, 2015).

Basically there are five methods of determining evaporation: water budget method, mass transfer method, energy budget method, pan evaporation method and combined method, see (Brutsaert, 2005), (Maidment, 1993). Each of these methods could yield different equations despite the basic ideas being the same. This could be caused by different approaches to determination of involved empirical constants and coefficients (Dlouhá \& Dubovský, 2019).

\section{Characteristics of the area}

Our study area, Lake Most (Fig.1) was created by the hydric recultivation of Most - Ležáky quarry, which was situated in the central part of the North Bohemian brown coal basin. Before the flooding of the area of the residual pit a whole lot of sanitation works had to be done, such as building sewerage of the future lake, construction of the underground sealing wall, construction of the banks, according to the law in the Czech Republic. All these landscape interventions were done with respect to the future usage of the lake (Dlouhá \& Dubovský, 2019). The Lake Most is a closed system without natural inflow or outflow. The residual pit of the lake was filled through a feeder from Nechranice industrial water pipeline from the Ohře River in 2008-2014. The current lake area is 309.4 hectares with a water volume of 70.5 million cubic meters and a maximum depth of 75 meters. Until September 2020, the waterworks was operated in the validation regime, now it serves as a recreational area.

\section{Materials and methods}

We have procesed a long-term series of measurements in monthly averages from the Kopisty meteostation data provided by the Institute of Atmospheric Physics of the CAS. The results in annual averages are complemented by a trend as well as a regression line. The trend line is a line drawn over pivotal heights or below the pivotal minimum that indicates the predominant direction of the quantity to be monitored. The regression line is interspersed with a set of pivotal heights.

The trend is not unequivocal when comparing annual precipitation totals (Fig. 2). Using the trend line (a), its variation 


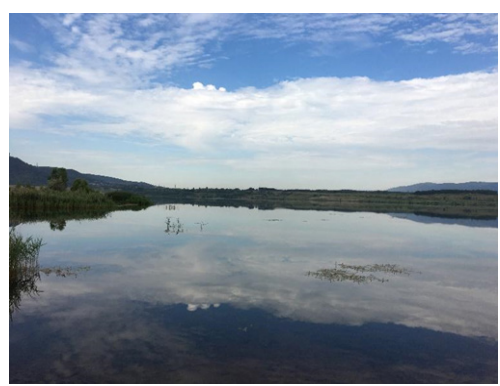

Fig. 1. The Lake Most

Rys. 1. Jezioro Most

with the variation in annual precipitation can be seen. If the regression line is used, there is an upward trend (b).

Temperature processing results indicate that the average annual temperature (Fig. 3) is increasing in trend using both the trend line (a) and the regression line (b). This rise is estimated to be $2^{\circ} \mathrm{C}$, for the reporting period 1970-2018.

Annual wind speed averages (Fig. 4) fluctuate greatly, so does the trend line (a). However, when the regression line (b) is intersected, we can talk about a small decrease.

The comparison of annual sunshine averages (Fig. 5) clearly shows an increasing trend using both methods (a), (b).

Moisture, which has been on a sustained trend throughout the monitored period, has experienced fluctuations in recent years (Fig. 6) which are followed by the trend line (a). In a linear regression, the line is slightly rising (b), despite the evaporation being more subnormal in recent years.

Comparison of annual evaporation $\mathrm{E}_{\mathrm{Th}}$ from the Kopisty meteostation data in the period 1970-2018

Data from 1970-2018 is available in monthly averages. Therefore, the Thornthwaite method for the month step (1) was chosen to calculate the evaporation.

The Thornthwaite method is the most frequently cited method for determining evaporation. A more detailed description of the method can be found in books (Wilson, 1974), (Davie, 2008), or (Gerosa, 2011). In those books reference is made to an article (Thornthwaite, 1948) in which Thornthwaite derives the formula and further uses it to classify the climate, i.e. to divide it into perhumid, humid, moist subhumid, dry subhumid, semiarid and arid regions.

It uses a monthly or annual temperature index to determine the monthly evaporation rate alone, $\left.\mathrm{i}_{\mathrm{m}}=\left(\mathrm{Ta}_{\mathrm{m}}\right) / 5\right)^{1,514}$ resp. $\mathrm{I}=\sum^{12}{ }_{\mathrm{m}=1} \mathrm{i}_{\mathrm{m}}$, where $\mathrm{Ta}_{\mathrm{m}}$, where $\mathrm{Ta}_{\mathrm{m}}$ is the average air temperature in the $\mathrm{m}$-th calendar month. The annual temperature index I is thus calculated from the long-term/monthly temperature averages of $\mathrm{Ta}_{\mathrm{m}}$ for the whole year. In the calculation of $\mathrm{E}_{\mathrm{Th}}$ itself, $\mathrm{Ta}_{\mathrm{m}}$ indicates the average air temperature in the month in which we are to determine the evaporation and the resulting $\mathrm{E}_{\mathrm{Th}}$ value corresponds to the evaporation in millimetres per month $\left(\mathrm{mmm}^{-1}\right)$.

In months in which the average temperature of $\mathrm{Ta}_{\mathrm{m}}$ is negative, the monthly index $i_{\mathrm{m}}$ shall be set equal to zero, and so shall $\mathrm{E}_{\mathrm{Th}}$ itself be zero in that case. For positive $\mathrm{Ta}_{\mathrm{m}}$ values, the monthly total of evaporation $\mathrm{E}_{\mathrm{Th}}$ is calculated as follows:

$\left.\mathrm{E}_{\mathrm{Th}}=\left(10 \mathrm{~T}_{\mathrm{a}}\right) / \mathrm{I}\right)^{675.10^{-9} \mathrm{I}^{3}-771 \cdot 10^{-7} \mathrm{I}^{2}+1792 \cdot 10^{-5} \mathrm{I}+0,49239}$

Since this is a temperature equation, we can see a similar trend and increase as for temperature (Fig.7).
Comparison of the annual evaporation E_Rom from the Kopisty meteostation data from the period 1970 - 2019

The Romanenko method (2) is, after the Thornthwaite evapotranspiration determination method, another method that works in a monthly step. It is described by the following relationship

$\mathrm{E}_{\mathrm{Rom}}=0,0018 \cdot(100-\mathrm{RH}) \cdot\left(25+\mathrm{T}_{\mathrm{a}}\right)^{2}$

where $\mathrm{T}_{\mathrm{a}}$ and $\mathrm{RH}$ denotes average air temperature and relative air humidity, respectively.

As in the case of Thornthwaite, we can see an increasing trend in evaporation in Romanenko, even though this equation depends not only on temperature but also on humidity (Fig. 8).

\section{Results and discussion}

The research team, which was established thanks to the support of the "CzechAdapt - System for the exchange of information on climate change impacts, vulnerability and adaptation measures in the Czech Republic" project published their prediction of the future development of climate conditions on the project's website (www.ecosystemservices.cz).

A comparison of the average annual precipitation averages for the period 1970-2018 and the forecasts for the period 20212100 show that the amount of precipitation should be similar. However, the average air temperature will rise.

When assessing the amount of water in our landscape, we have to take into account that the extremes of precipitation have become increasingly dynamic in recent years. The increase in air temperature over the period from 1970 to 2018 is demonstrable, but the steady state of annual precipitation is statistically confirmed. These findings indicate that the frequency of droughts may be increasing, as evidenced by these evaluations.

Compared to the averages of temperatures and precipitation in the Czech Republic, the area of planned hydric reclamation is situated in an area of severely above-normal average annual temperature, a strongly sub-normal total of precipitation and a sub-standard number of hours of sunshine.

Each area has its own specific conditions and is also different within a single study area. The reason why it is important to have the best measured climate data in a long-enough time series is captured by the graph (Fig. 9) showing the percentage increase in annual evaporation if the average temperature increases by 1 degree and if it increases by 3 degrees.

Since we have daily step data for 2014-2018, we were able to determine the effect of temperature rise on free water surface evaporation using the Penman - Monteith equation, which works with daily step data. 


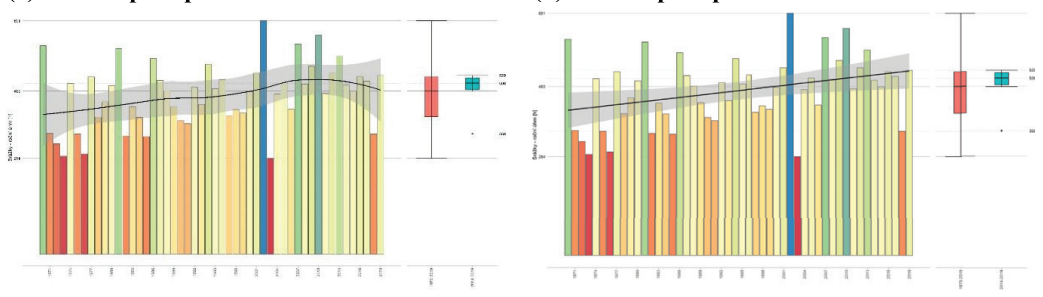

Fig. 2. Comparison of the annual precipitation based on the data from the Kopisty meteostation in $1970-2018$ supplemented with the trend line (a) and the regression line (b)

Rys. 2. Porównanie opadów rocznych na podstawie danych z meteostacji Kopisty w latach 1970 - 2018 uzupełnionych o linię trendu (a) i linię regresji (b)

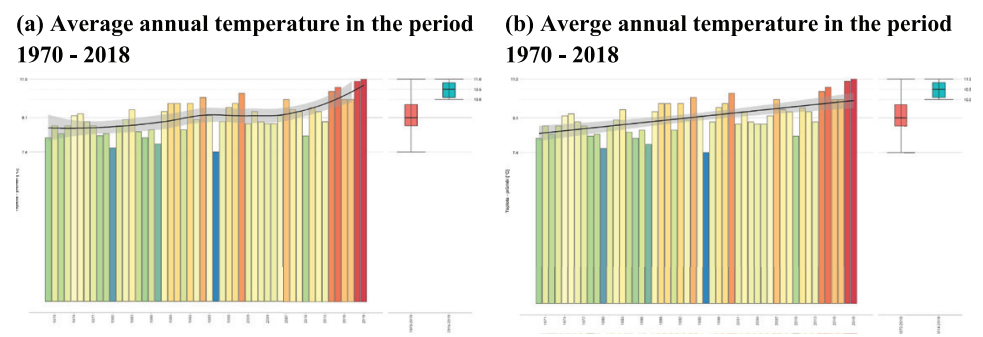

Fig. 3. Comparison of the annual temperature averages from the Kopisty meteostation data from the period 1970-2018 supplemented with the trend line (a) and the regression line (b)

Rys. 3. Porównanie rocznych średnich temperatur z danych meteorologicznych Kopisty z lat 1970-2018 uzupełnionych o linię trendu (a) i linię regresji (b)

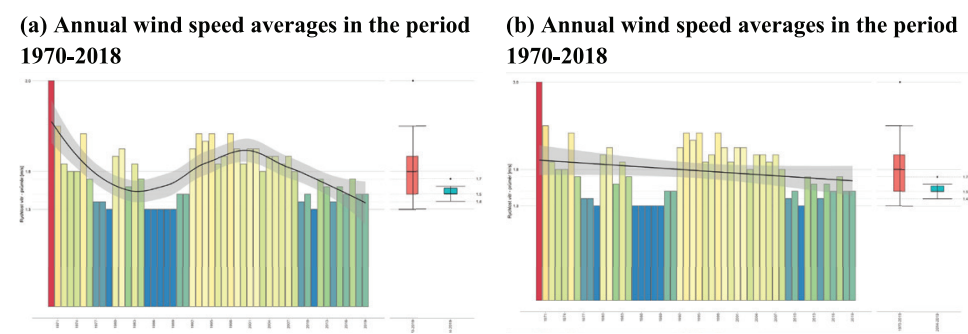

Fig. 4. Comparison of the annual wind speed averages from the Kopisty meteostation data from the period 1970-2018 supplemented with the trend line (a) and the regression line (b)

Rys. 4. Porównanie rocznych średnich prędkości wiatru z danych meteorologicznych Kopisty z lat 1970-2018 uzupełnionych o linię trendu (a) i linię regresji (b)

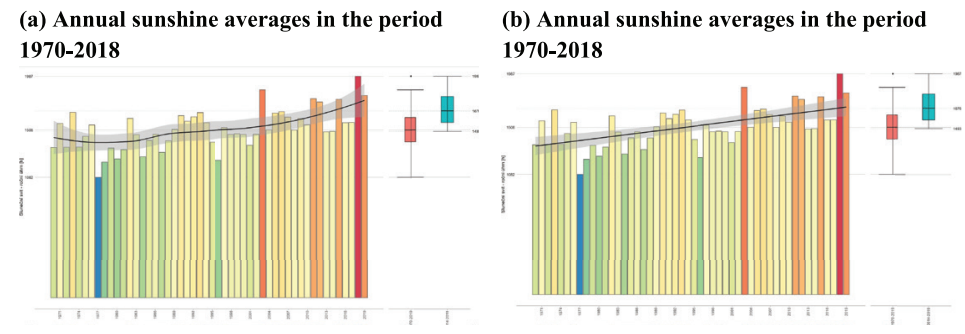

Fig. 5. Comparison of the annual sunshine averages from the Kopisty meteostation data from the period 1970-2018 supplemented with the trend line (a) and the regression line (b)

Rys. 5. Porównanie rocznych średnich nasłonecznienia z danych meteorologicznych Kopisty z lat 1970-2018 uzupełnionych o linię trendu (a) i linię regresji (b)

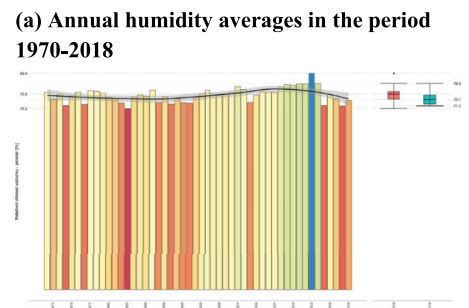

(b) Annual humidity averages in the period 1970-2018

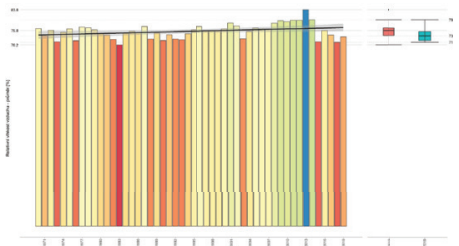

Fig. 5. Comparison of the annual sunshine averages from the Kopisty meteostation data from the period 1970-2018 supplemented with the trend line (a) and the regression line (b)

Rys. 5. Porównanie rocznych średnich nasłonecznienia z danych meteorologicznych Kopisty z lat 1970-2018 uzupełnionych o linię trendu (a) i linię regresji (b) 

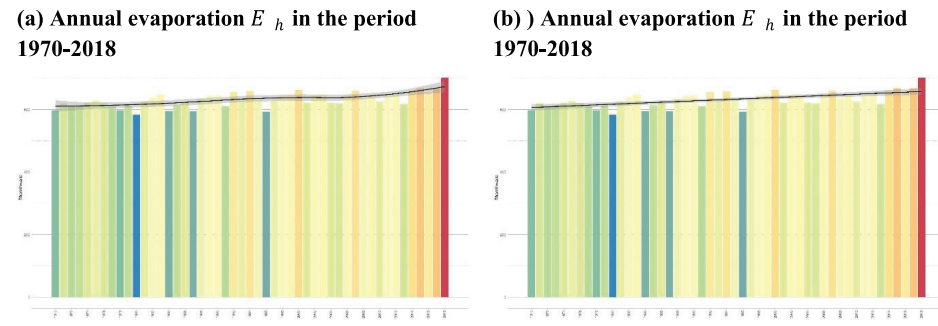

Fig. 7. Comparison of the annual evaporation $\mathrm{E}_{\mathrm{Th}}$ from the Kopisty meteostation data from the period 1970-2018 supplemented with the trend line (a) and the regression line (b)

Rys. 7. Porównanie rocznego $\mathrm{E}_{\mathrm{Th}}$ parowania $\mathrm{z}$ danych meteorologicznych Kopisty z okresu 1970-2018 uzupełnionych o linię trendu (a) i linię regresji (b)

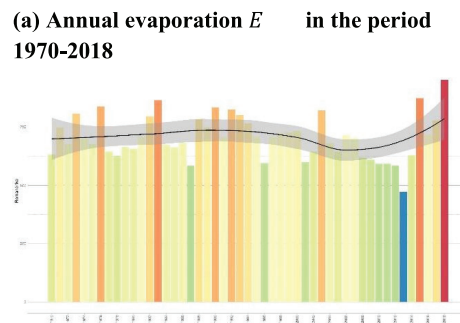

(b) Annual evaporation $E \quad$ in the period 1970-2019

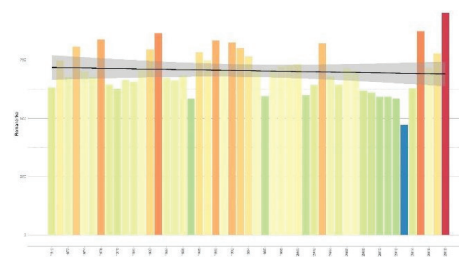

Fig. 8. Comparison of annual evaporation $\mathrm{E}_{\mathrm{Rom}}$ from the Kopisty meteostation data for the period 1970 - 2018 supplemented with the trend line (a) and the regression line (b)

Rys. 8. Porównanie rocznego $\mathrm{E}_{\text {Rom }}$ parowania $\mathrm{z}$ danych meteorologicznych Kopisty z okresu 1970 - 2018 uzupełnionych o linię trendu (a) i linię regresji (b)

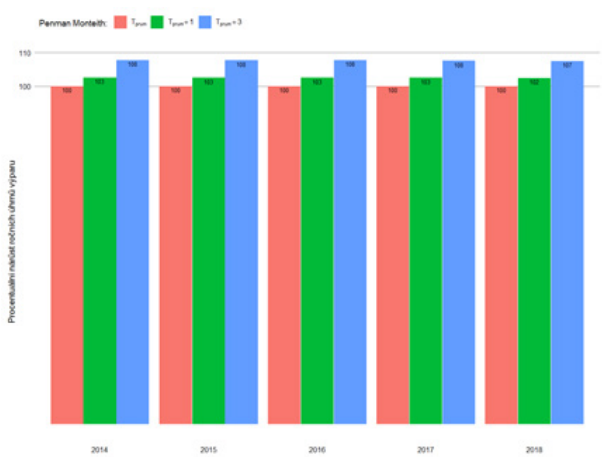

Fig. 9. Percentage increase in annual evaporation

Rys. 9. Procentowy wzrost rocznego parowania

In the work (Allen et al., 1998) FAO (Food and Agriculture Organization of the United Nations) recommended The Penman-Monteith equation in the form (3) as standard estimation method.

$$
E_{F A O}=\frac{0.408 \Delta\left(R_{n}-G\right)+\gamma \frac{900}{T_{a}+273} u_{2}\left(e_{s}-e_{a}\right)}{\Delta+\gamma\left(1+0.34 u_{2}\right)}
$$

The $\mathrm{E}_{\mathrm{FAO}}$ denotes the evapotranspiration intensity in $\mathrm{mmd}^{-1}$ and it is calculated using the following variables and constants. The term $\Delta$ represents the slope of the water vapor saturation curve at a given air temperature, $R_{n}$ is the net radiation on the surface, and $\mathrm{G}$ is the heat storage change in soil or in water, both $\mathrm{R}_{\mathrm{n}}$ and $\mathrm{G}$ are expressed in $\mathrm{MJm}^{-2} \mathrm{~d}^{-1}$. According to Linacre article (Linacre, 1993) for daily or monthly estimates of the evaporation rate of free water level the term $\mathrm{G}$ can be neglected, i.e. set $\mathrm{G}=0$. The term $\left(e_{s}-e_{a}\right)$ in $\mathrm{kPa}$, is the difference of saturation vapor pressure and actual vapor pressure, $\mathrm{u}_{2}$ denotes wind speed in height $2 \mathrm{~m}$ above surface in $\mathrm{ms}^{-1}$. The constant $\gamma$ depends on atmospheric pressure $\mathrm{P}$ in $\mathrm{kPa}, \mathrm{T}$ is air temperature in ${ }^{\circ} \mathrm{C}$.
A long-term series of climate data shows that the average annual air temperature in the period 2014-2018 increased by about $2^{\circ} \mathrm{C}$ in comparison with the period $1970-2013$. As a result, free water surface evaporation is $5-6 \%$ higher. Simulating and predicting the further development of the hydrological balance of the study area following precipitation and air temperature scenarios for future periods and assessing the impact of climate change scenarios on the hydrological balance of the pilot area is therefore an essential part of preparing planned hydric reclamation. This is the only way to estimate the expected free water surface evaporation and use it to establish a long-term sustainable water balance in the study area.

\section{Acknowledgment}

This contribution has been completed thanks to the financial support provided to VSB-Technical University of Ostrava by the Czech Ministry of Education, Youth and Sports from the budget for conceptual development of science, research and innovations for the 2020 year. The authors would like to express further thanks to The Institute of Atmospheric Physics CAS for the provided meteorological data from their measuring station Kopisty.

\section{Conclusion}




\section{Literatura - References}

1. Beran, A., Hanel, M. (2015). Definování zranitelných oblastí z hlediska nedostatku vody na území České republiky. Vodohospodářské technicko-ekonomické informace, roč. 57, č. 4-5, s. 21-24. ISSN: 0322-8916.

2. Brutsaert, W. (2005). Hydrology: an introduction. New York : Cambridge University Press. ISBN 978- 0521824798.

3. Maidment, D. R. (1993). Handbook of hydrology. New York : McGraw-Hill. ISBN 0070397325.

4. Dlouhá, D., Dubovský, V. (2019). The Improvement of the Lake Most Evaporation Estimates. Inżynieria Mineralna, vol. 43, iss. 1, pp. 159-164. ISSN 1640-4920. DOI: 10.29227/IM-2019-02-28.

5. Wilson, E.M. (1974). Engineering hydrology; Macmillan: London New York.

6. Davie, T. (2008). Fundamentals of hydrology, 2nd ed ed.; Routledge: Abingdon England.

7. Gerosa, G. (2011). Evapotranspiration: from measurements to agricultural and environmental applications; InTech: Rijeka, Croatia.

8. Thornthwaite, C.W. (1948). An approach toward a rational classification of climate. Geographical review, 38, 55-94.

9. http://www.ecosystemservices.cz/cs/czechadapt-system-pro-vymenu-informaci-o-dopadech-zmeny-klimatu-zranitelnosti-a-adaptacnich-opatrenich-na-uzemi-cr/

10. Allen, R. G., Pereira, L., Raes, D., Smith M. (1998) "Crop evapotranspiration-Guidelines for computing crop water requirements-FAO Irrigation and drainage” paper 56 in Vol. 56, United Nation - Food and Agriculture organisation.

11. Linacre, E. T. (1993). "Data-sparse estimation of lake evaporation, using a simplified Penman equation", Agricultural and Forest Meteorology, 64, 237 - 256. DOI:https://doi.org/10.1016/0168-1923(93)90031-C.

Określenie charakterystyki klimatu w badanym obszarze projektowanej rekultywacji wodnej Jezioro Most jest wyjątkowe w tym sensie, że nie ma naturalnego dopływu i odpływu, dlatego konieczne było wybudowanie sztucznego dopływu rzeki Ohře. Głównym celem prowadzonych badań jest zbudowanie modelu matematycznego prognozującego bilans wodny jeziora Most. Dlatego ważne jest, aby zbilansować ilość wody traconej w wyniku parowania od ilości wody traconej do podłoża. Poza zależnościami od temperatury, wykorzystano bardziej złożone metody i równania do obliczenia efektu parowania, uwzględniające wartości wilgotności względnej, ciśnienia atmosferycznego, prędkości wiatru i długości dnia. Oprócz danych klimatycznych potrzebnych do obliczenia parowania, w równaniach bilansu uwzględniono ilość opadów. Ważnym celem przy planowaniu rekultywacji wodnej jest zapewnienie długoterminowej trwałości, co opiera się na szczegółowym opisie klimatu i lokalnych warunków hydrologicznych badanego obszaru. W naszym artykule skupiono się na ocenie ewolucji klimatu w badanym obszarze rekultywacji wodnej. Przetworzono serię długoterminowych pomiarów w średnich miesięcznych z danych meteorologicznych Kopisty dostarczonych przez Instytut Fizyki Atmosfery CAS.

Słowa kluczowe: klimat, parowanie, rekultywacja wodna, jezioro Most 